\title{
PROCESSES OF REFORMATION IN DONNE'S DEVOTIONS UPON EMERGENT OCCASIONS: BELLS, BRASS, AND THE READER'S WORK
}

If what many people know of Donne's Devotions upon Emergent Occasions-perhaps even of Donne, period - is the invocation that "no man is an island", a close second is the injunction not to "send to know for whom the bell tolls", and its attendant promise that it "tolls for thee". ${ }^{1}$ The bell not only speaks to the relationships between individuals and communities that are so important to this text, but it also operates as a symbol, a marker, and a prompt all the way through the account of Donne's sickness and his recovery. Bells are the most prominent object in the Devotions, ringing through the whole text and occupying a privileged space as the focus of three central stations, which describe the peak and the break of Donne's fever, and the death of his neighbor. Although this sequence is the most associated with bells, Donne hears them throughout: they not only mark clock time, but remind him unrelentingly of sickness, dying, and death. The bells are both spread through and absolutely at the heart of this work.

Another commonplace, at least in scholarly work on the Devotions, is that this is a text profoundly concerned with the conceit of the body as dissolvable and changeable - and the relationship this has with wider concerns about the individual and the community, the body and the soul. In this essay I reveal the connections between these two points of understanding about the Devotions. There are many bodies that dissolve (or have the potential to dissolve) in the work: Donne's own; the bodies of his neighbors who are dying all around him; the overlapping social bodies of which he is a part; the body politic. ${ }^{2}$ To this list we must, I argue, add the bodies of the bells Donne hears. Far from being merely sounds and symbols in the Devotions, bells are 
also massy, weighty things - and they are always on the point of being melted down and remade. In the Devotions as in the sermons, Donne uses sculptural processes - in particular, the melting of metal that prepares it to take on new form - as analogues for the productive crisis that he finds in his bodily and spiritual sickness.

Donne builds on the established understanding of bells as subjects, with voices and identities, whose speech acts were written out in the inscriptions that often ran round their exteriors. These were objects that were felt to have a kind of a life, and in the Devotions Donne joins conversations about their tenacious survival as objects, practices, and sounds in the postReformation church. In the 1620 s, a period in which bell-casting was being revived and bells remade, this was an increasingly common trope shared by far less serious writers than Donne who also wrote about the processes of bells' (re)casting as a purification of the body. In the Devotions bells are not only destructible objects but destructible bodies, too.

The artisanal poetics that Donne develops to discuss the bells in his work has a further consequence. Donne's reliance on processes of re-making echoes in the Devotions both formally and in the response that the text demands: as a template for the work of both writing and reading. Bells and their recasting in the post-Reformation church offer a particular set of metaphors with which to think through ideas of form, matter, and — in particular — the processes that rework matter into new forms. The repeated melting and solidifying of metal provides a model for the effort that is required of the Devotions' reader. The modular, recursive form of the text shows its own making, and invites a particular form of labor - a careful, individual, repetitive and nonsequential reading — in order to work through the whole. If literary study is often preoccupied 
with the poles of form and of matter, and their theoretical homes in formalism and materialism, here I show how Donne emphasizes the processes of formation that act as a middle term between the two. In doing so I join other recent studies that focus on how, and why, English renaissance writers made manifest the activity of making. ${ }^{3}$ Many of them made much of the root of the English word "poesy" in the Greek poiein. Puttenham, for example, begins his Art of English Poesy with the declaration that "[a] poet is as much to say as a maker". ${ }^{4}$ Jonson was particularly keen to emphasize poiesis [AUTHOR'S NOTE: needs macron over "e"], that is, the process of making: "Poesy", he writes in Timber; or, Discoveries, "is his [the poet's] skill, or Crafte of making $[\ldots]$ these three voices differ, as the thing done, the doing, and the doer; $[\ldots]$ so the Poeme, the Poesy, and the Poet". ${ }^{5}$ By separating out the three terms here, Jonson encourages us to consider them individually, and carefully. And when Donne puts making-Jonson's "doing" - at the heart of the Devotions, he shows how not only the creative practices of manufacturing and writing, but also the receptive modes of listening and reading, are processes that require work.

\section{LIVING BELLS AND LIVING METAL}

"NON SONO ANIMABVS MORTVORVM SED AVRIBUS VIVENTIUM” ("I sound not for the souls of the dead but to the ears of the living"): thus reads the inscription on a bell cast in the early seventeenth century by Richard Holdfield of Cambridge. ${ }^{6}$ The second part of the inscription declares the bell's current use, to alert the living people within earshot; the first gives an echo of its former function to ring for the dead, helping the passage of the soul through purgatory. This object was likely made from the metal of an earlier bell that had been melted 
down and reformed. Its matter is the same, its form changed to include this new inscription that spells out, in a rather defensive palimpsest, its altered function. Pre-Reformation bell inscriptions often took the first person, or the imperative ("IOHANNES EST NOMEN MEVM"; "SANTA KATARINA ORA PRO NOBIS”, etc), but this one develops older traditions to position itself more densely within subject-object relations that direct, or even constitute, the community it serves. ${ }^{7}$ Holdfield's bell and its inscription establish some characteristics about seventeenthcentury bells which are taken up by Donne in the Devotions. First, they are subjects, with voices, and they speak in the first person. Second, they have clearly defined functions in the postReformation church — but they remember their old ones, even if only to deny that they do them any longer. Third, and related to the second: in their inscriptions, they announce their own interpretation, calling their living listeners to correctly hear their message. Fourth, they were being newly cast in the early years of the century, their matter melted, their form dissolved and re-made.

Bells were contested objects in the post-Reformation Church of England. As objects of the old religion their inscriptions often bore invocations to saints, and they may have been baptized into the church. They were never entirely banned but were subject to quixotic reforms, not just in the pendulum swings between Protestantism and Catholicism in the first half of the sixteenth century, but also within the reigns of individual monarchs. ${ }^{8}$ Although some bells were sold as scrap metal and melted down many managed, sometimes against the odds, to survive the religious upheavals of the sixteenth century. Large monastery bells taken down in the 1530 s were often not destroyed but redistributed and bought by parish churches. The reformation that happened to old bells was thus not one of matter or form, but largely one of practice. The 
survival of so many bells was, Margaret Aston writes, "like so much else in the English Reformation [...] in a sense a fortuitous result, a by-product of the Reformation that did not happen". 9

This story of reuse and redistribution caused a marked downturn in English bell-casting at the end of Henry's reign and through Edward's. ${ }^{10}$ Holdfield's bell, made at the beginning of the seventeenth century, signals an important new chapter to the story of bells' material survival in the post-Reformation period. In the final decades of the sixteenth century, they began to be remade on a large scale. The protean nature of bells makes it difficult to determine exactly how many were cast when, but the general picture seems to show a lull in the middle of the century which picked up in the 1570 s, accelerated up to the period of the civil wars, during which there was another lull, which increased again afterwards. ${ }^{11}$ In the decades leading up to 1600 , then, and throughout the seventeenth century (with an interruption from 1640-60), the fallow practice of bell-founding came back to life.

Bells are made from a mixture of copper and tin: an alloy that is durable, resistant to rust, and remarkably sonorous. The combination of copper and tin is now described by the word bronze, a word borrowed from Romance languages which didn't attain common currency in English until the eighteenth century. Early modern English used, instead, the word brass to describe all copper alloys (including copper and zinc, still known as brass; and copper and tin, now known as bronze). The term "brass" is therefore necessarily imprecise, and includes bronze, as well as other things - it's a capacious word for a capacious substance, often made not to an exact recipe but of a mixture of copper with whatever other metals happened to be lying around. ${ }^{12}$ 
The casting process employed language and concepts that extended the widespread understanding of the bell as a subject: something profoundly person-like, with not just a name and a voice but a shoulder, a collar, a tongue, and a birth, too. Casting involved making a precise hollow space between an inner and outer mold, known respectively as a core and a cope. ${ }^{13}$ The whole mold, covered in a mixture that might include clay, dung, and goat hair, was buried in a pit - sometimes dug in the church grounds. The bell-founder heated up the metal, and poured the molten alloy into the mold; the now-fluid bronze sought out the corners of the mold and took on the shape of this negative space, becoming as it hardened the main form of the bell itself. Fine details, like the inscription round the bell's shoulder, or collar, also took shape in the pour. The metal was left alone to harden and cool, for days or weeks, then dug out to reveal the finished object. This process could represent not just a birth but a rebirth: bells might be re-made from the same metal, given a new form while retaining their old name and their old identity. This had been the case throughout the medieval period, and continued after the Reformation too. ${ }^{14}$ Like Holdfield's bell, speaking with a continuous "I", matter could carry identity despite the wholesale transformation of form.

As the processes of their birth, the nomenclature of their shape, and their names and identities suggest, bells were felt to be alive: not just in their bodies and their voice but in the metal from which they were made. From ancient civilizations onwards, bronze was thought to have a particular vitality in the way in which it could imitate the human body in texture and tone; founders treated the metal as a substance which could have needs, desires, and behavior that had to be understood and respected. ${ }^{15}$ In her new materialist manifesto Vibrant Matter Jane Bennett, 
following Deleuze and Guattari, asks "Is there such a thing as a [...] metallic life?"16 The answer would have been obvious to premodern people. Bells propose a particular variety of "metallic life" in early modern England: one related to Bennett's vital materialism, not anachronistically but as a part of the prehistory of her ideas. The liveliness of these objects and the metal of which they are made display a liveliness that inhered in and between matter, form, and process: a life that could be remade, over and over, strengthened and improved every time.

\section{THE POETRY AND POETICS OF BELL-CASTING IN THE 1620s}

Before turning to Donne, I want to investigate some other contemporary readings of the liveliness of bell-metal. In a clutch of widely commonplaced poems Richard Corbett (Dean of Christ Church, Oxford, 1620-28; Bishop of Oxford,1628-32) and his imitators commemorate the recasting of important bells, including the Great Tom bell at the college, probably in $1626 .{ }^{17}$ If not an equivalent to Donne, Corbett was at least his contemporary-one who also drew on bells' histories and visible manufacture in the $1620 \mathrm{~s} .{ }^{18}$ The Great Tom bell encapsulates the story of the reuse and reformation of old bells: it (along with seven others) was taken after the Dissolution from Osney Abbey, just west of Oxford, to the former priory of St Frideswide's, which in 1546 became jointly Oxford Cathedral and the chapel of Christ Church. ${ }^{19}$ It hung there through most of the seventeenth century until it was installed in 1682 in the gateway tower of the college, where it remains. Though its name and much of its metal remained constant, however, the bell underwent many recastings. And in Corbett's poem, the re-founding of this giant, old bell is refigured as a re-birth. 
"[T] day", writes Corbett, of the day in which the bell was recast, "Is yonge Toms resurrection from the clay". The poem continues:

Old Tom's growne yonge againe: the fiery cave

Is now his cradle that was erst his grave.

He grewe upp quickly from his mother earth,

For all you see is not an howres birth.

Looke on him well: my life I dare engage

You nere saw preteyer babie of his age. ${ }^{20}$

These lines push metaphors of birth and death to their limit, for comic effect. The founder's furnace — the "fiery cave" — acts as both grave and cradle; in melting, the bell dies — and yet this change of state is what allows it to be reborn. The bell is buried in the ground ("his mother earth"), and at the end of the poem the bell, described as a martyr, dies another kind of death, when put back in the tower: "Wee all be glad, great Tom, to see thee hanged". ${ }^{21}$ In a reversal, even lampoon, of the genre of the child elegy, death is celebrated at every stage as an improvement: making the bell "preteyer", younger, and — when hung again in the tower-a source of joy for all. If there is any mourning here at all it is for the monastic foundation from which the bell originally came. A few stanzas later Corbett addresses the ruined Osney Abbey:

Nere grieve, old Oseny [sic], at thy heavy fall.

Thy reliques build thee up againe. They all

Flourish to thy great glory; Their sole fame

When thou art not will keep great Osenys name. ${ }^{22}$

In this passage, formally more disjointed than elsewhere in the regular rhyming iambic pentameter of this poem, cesurae signal the separated parts, like the bells, taken away after the 
dissolution. The abbey's bells, many of which were transferred to Christ Church—Osney is “of Gyante bells the famous treasury"- operate as the monastery's legacy, descendants that continue the family name. ${ }^{23}$

The bells work not only to memorialize Osney but also as a kind of material recreation of the ruin: "reliques" that "build thee up againe". The sight of the old ruined abbey seems to prompt Tom's spontaneous dissolution: "But when hee saw the old foundation/ And little hope of reparation,/ Hee burst with griefe", the poem continues. ${ }^{24}$ And yet it's this bursting, and the melting he undergoes in the founder's furnace, that makes him new again. The agency of the founder is important: many similar poems extol the skill of the metal-caster, and indeed mention local bell-founders by name. "To the Bell-Founder of Great Tom of Christ Church in Oxford", probably by a writer in Corbett's coterie, echoes Corbett to praise the bell-founder as "Thou that by ruine doest repaire", and his art as one that "doth tell us what men are,/ Who by corruption shall rise sounder". ${ }^{25}$ Matter or metal carries identity, rather than form-form is subject to ruin at any time, but vitality is both displayed and renewed in the process of reformation.

Corbett's poem prompted others from members of his circle, and the frequency with which verses from this group appear in commonplace books indicates that they were a popular genre. ${ }^{26}$ One plays up even more than others to the idea of the bell as a subject, with voice and volition. Here Great Tom is a "phoenix", hatched from "nursing ashes" who

Heauie with woe hee like a Hermite gaue

His mortified bodie to a caue.

He burst with greif for his defects, and then 
Melted with zeale to be restord agen ${ }^{27}$

As the lines peal with dactyls, the author emphasizes again and again the bell's agency: bursting with grief (a direct echo of Corbett's poem) and melting with zeal he dissolves himself willingly; later, he "threw himself freely" to the cave of the mold, and "ran through the fire" as liquid bronze. ${ }^{28}$ The founder's craft here seems secondary to the active movement by the heroic bell. He survives the trial of the fire; in returning safe and well he proves himself to be the same bell, the same object, as before—but stronger, indeed "as sound as any bell". ${ }^{29}$ Reforming effects a redemption of the bell's strength and power. "For hee's all mettall", the poem continues, probably intended as a pun on the meaning of the word as life-force, or semen: the bell has rebirthed, re-cast himself. ${ }^{30}$

These poems, corny though they are, give Great Tom a recurring narrative of rebirth. Corbett and his imitators offer an optimistic reading of bodily crisis which can, if entered into willingly like the bell gleefully running into the fire, provide opportunities for regeneration. The founder's art can even "tell us what men are": the bell's lifespan, and especially its renewal, can also work as an analogue to the passage of human life. The famous line about bells in the Devotions_-"never send to know for whom the bell tolls; It tolls for thee" (87) - encourages an interpretation of bells as aural presences that signal death's imminence and wide dominion. Corbett makes us aware of a supplementary reading of bells in the Devotions (and in his own work) that is not just about death, or about sound. Bells are also living objects, with material histories, that can offer a model for how to be reborn.

\section{THE BODIES OF BELLS IN THE DEVOTIONS}


The bell that "tolls for thee" falls in the $17^{\text {th }}$ Meditation, in the middle of the bell sequence (Devotions 16-18). This sequence marks a midpoint of the narrative, when Donne's fever peaks and breaks. Throughout these central stations the bells communicate to Donne the passage of his dying neighbor from sickness to death and burial. In fact the sequence is related somewhat in reverse: Donne begins by discussing bells and funeral practices more generally ( $16^{\text {th }}$ Devotion), a response to the frequent funeral ringing that he can hear from his sickbed..$^{31}$ The bells of the $17^{\text {th }}$ Devotion have a more specific target: here Donne listens to the bells being tolled to mark the passing of one individual's soul this incredibly dense $17^{\text {th }}$ Meditation makes this personalized tolling universal. ${ }^{32}$ Donne describes the dying man hearing his bell tolling, and extrapolates to show how this individual instance of listening implicates the whole Christian communion: "this Bell calls us all" (86). In the second half of the Meditation, bells and ringing set up the most famous parts of the whole work about islands and continents, the appeal to not ask for whom the bell tolls, and tribulation as treasure, heavy metal, "gold in a Mine" (87). The $17^{\text {th }}$ Devotion is about flux: souls, voices, communities, continents are interchangeable, and in motion. The $18^{\text {th }}$ returns to a kind of stillness, in which the bells tell Donne that his neighbor has died. "Mortuus es", reads the part of the Latin poem that prefaces this Devotion: "I am dead" (91), a refrain that echoes like a tolling bell in the Prayer at the end of this station (96). Death is no longer encircling and getting closer, but is now something that's already true, and always has been. Throughout, it is difficult to separate out the bells, their sounds, the bodies of the sick, and Donne's own writing of them all. For Donne objects are always, as Elaine Scarry writes, "language-soaked", and none more so than the bells in the Devotions, literally wrapped in letters, whose inscribed surfaces undergo iterations of rewriting in the text. ${ }^{33}$ 
Donne takes seriously the physical qualities of the bells in the Devotions. The bell sequence displays a concern with the weight of these objects, their previous lives as shapeless metal —and their capacity to become so again. In the $16^{\text {th }}$ Meditation, Donne imagines the quantity and bulk of the bells he hears now and the bells he's heard before: once, he lay near "a steeple, in which there are said to be more than thirty Bels; And neere another, where there is one so bigge, as that the Clapper is said to weigh more than six hundred pound" (82). He imagines these bells, in Antwerp and Rouen respectively, as sounds but also as heavy, weighty things. Elsewhere in the passage Donne, like Corbett, seems to comment on the post-Reformation histories of bells and the recent revival of bell-casting in England. He pays particular attention to the way in which bells, as molten brass, are poured into other molds, and become something else. "When the Turkes took Constantinople", he writes, "they melted the Bells into Ordnance" (82). Political and religious conversion is reflected in this significant change of form. Bells and cannon were materially equivalent, made from the same variety of bronze — symbols of peace and war easily and frequently transformed one into another. This is an echo of the fate of some English preReformation bells: Margaret Aston suggests that a number of abbey bells "went to the gun foundry in the Tower", following the example of St Gall under Zwingli, in which at least 14 bells were melted down in the 1520 s to make a single large cannon. ${ }^{34}$ The giant bell Donne mentions having heard in Rouen was itself melted down for cannon in $1793 .{ }^{35}$ The sound of these two objects were analogous, too: bells and cannon would have been some of the loudest humanlyproduced noises in the early modern soundscape. Donne suggests their aural equivalence, or at least comparability: "I have heard both Bells and Ordnance", he writes, "but never been so much affected with those, as with these Bells" (82). Cannon boom through the Devotions, and 
especially through the Meditations (the most worldly of his three categories of devotion), as echoes of the bells that ring. In fact the onset of fever is heralded, even caused, by cannon: one minute a man is in perfect health; the next, Donne writes in the first Meditation, "a Cannon batters all" (7). Cannon are both the occasion and the result of liquidation and conversion; bells and ordnance signal to Donne the terrifying but generative force of sculptural transformation.

\section{V. “LIKE BRASS MELTED IN A FURNACE”: FEVER, CRISIS, AND SCULPTURAL PROCESS}

Throughout the Devotions, the bell is implicated as being invested and complicit in Donne's own corporeal and spiritual vulnerability. Here bells ring in a landscape, and a soundscape, in which bodies change shape. In these pages, and particularly through the 23 Meditations, earth, water, and metal flow and fuse into each other and out again. While his body is on the point of destruction, Donne conceives of all bodies as mutable, meltable, and capable of radical reformation. Bells and bell-metal (that is, bronze) are part of this fluid landscape.

Metal and the craft of its manipulation appear in the Devotions even before we encounter bells. In a series of passages beginning in the second Meditation Donne links health and sickness to sculptural process. He figures God as the true artisan and melting, represented in the body as fever, as one of the divine processes of bodily and spiritual reformation. "Man, who is the noblest part of the Earth", he writes in a much-quoted passage, melts so away, as if he were a statue, not of Earth, but of Snowe. We see his owne Envie melts him, hee growes leane with that; he will say, anothers beautie melts him; but he 
feels that a Fever doth not melt him like snow, but powr [pour] him out like lead, like yron, like brasse melted in a furnace $[\ldots](11)$

In this brief passage the transformation of the body is multiple and complex. Donne describes the man first of all as a statue: a human creation, a piece of art, and one with a body constructed from a series of materials, all with their own processes and properties. All of these materials are meltable - the word "melt" and its derivatives occur five times in this short excerpt—but the properties of each kind of matter are important, because some are durable and others are not. One's own envy, or another's beauty, can turn a man from a statue of earth to one of snow, one that melts to water, and then to nothing. But a fever is able to effect yet more radical change. Rather than melting the man like snow, it "pours him out like lead", iron, or "brasse melted in a furnace". Donne's list of molten metals serves to show the power of the fever, able to transform all these metals — heavy lead, strong iron, and resonant brass—into a fluid state. The fever "pours", in a deliberate action intended not just to destroy, but also to re-form.

Donne seems to be drawing on Job 6:12: "Is my strength the strength of stones? or is my flesh of brass?" ${ }^{36}$ Here Job remonstrates with God, complaining that he is only human—not strong, like stone or brass - and can't bear the suffering that he is struggling through. Donne used this line many times in his sermons, in the way it is usually interpreted: to show how flawed and sinful humans are, their bodies made not of stone or brass, but of flesh corruptible and weak. But here in the second Meditation, and in times of suffering, flesh might in fact be like brass — brass not stable and solid, though, but lively and liquid. ${ }^{37}$ Melting can represent bodily or spiritual sickness: it reappears in the eighth Expostulation when a man who exhibits the sin of ungratefulness towards the sovereign is described as having a "universall illnesse, ready to flow, 
and power [pour] out it selfe into any mold" (42). In both cases, the sickness has such force that melting now produces not something watery like the snow statue, capable only of slipping away, but rather a newly-inchoate mass: brass ready to be cast again, alive and terrifying in its flow.

Donne's fascination with fluidity and liquid states has been much discussed. For Nancy Selleck, Donne's humoral, fluid body allows him to join with others in a model of "radically interpersonal selfhood"; Philip Schwyzer, too, writing on Donne's obsession with bodily putrefaction in the grave, suggests that corporeal liquefaction is, Schwyzer writes, "a way of joining with others, not closing himself off from them". ${ }^{38}$ These processes are particularly important in the Devotions, in which the point of the text is to explore or even implement the possibility that something personal can become something universal. John Carey, meanwhile, sees the melting trope as a vehicle through which Donne considers, or perhaps bemoans, the fragility and inconstancy of things — all of which ultimately reflect back on his own self: "the chaos of matter's changing states" is "a counterpart to [Donne's] own unfixedness". ${ }^{39}$ In a long succession of examples, Carey lists the various types of matter that melt in Donne's poetry and prose. What these show, he argues, is that because all matter is continually in the process of becoming something else, nothing — least of all human individuality—is stable; "[t]o suppose that you are the same person two days running is [...] scientifically unsound". ${ }^{40}$

Both schools agree that the most important moment is the moment of melting: for Selleck and Schwyzer, because this is when the joining with others occurs; for Carey, because this is the constant state of all things. Yet, in the Devotions in particular, Donne is concerned not just with the instant of liquidity but the period afterwards too, when the matter in question is productively 
re-formed. Fluidity is a recurring episode rather than a constant: matter (dissolved but not lost) is able to take on a new form, and this is a process that can be repeated, with both risk and opportunity in every cycle. Melting with the potential for reformation is an analogue to the kind of bodily and spiritual crisis that Ramie Targoff identifies as being so important for Donne. Sickness offers an opportunity for confronting the condition of both body and soul—an activity that is impossible in the quotidian state of good health. During the "transitional moments" of sickness, Targoff argues, God seemed "more accessible or present than during Donne's normal life". ${ }^{41}$ Fever is analogous to the melting of metal—after all, it causes Donne to feel "like brasse melted in a furnace". This transitional period, full of possibility, is for Targoff the location of "the delight that the Devotions provides":

the delight of being thrust in the middle of a crisis, of witnessing the vicissitudes of falling and rising, of understanding the struggle of sickness as something imaginatively and devotionally productive. ${ }^{42}$

This delight in the moment of melting is only possible, though, when one has faith that the body will afterwards be remade once more. Again and again in the Devotions, from the mention of his three births in the epistle to Prince Charles onwards, Donne invokes not only dissolution but also the subsequent, necessary reformation as being crucial to the health of body and soul.

What Targoff identifies, but Carey does not, is the cyclical nature of these processes - the "falling and rising", just like metal-casting, in which the matter can be completely broken and remade without loss. "Let God mould me, and then melt me againe, let him make mee, and then breake me againe", Donne writes in a sermon on the Penitential Psalms, part of a series of sermons on these texts that are likely to have been preached in the spring of 1623 , not long 
before his illness, and which echo in the Devotions. ${ }^{43}$ In this sermon, on 6.1 ("O Lord, rebuke me not in thine anger, neither chasten me in thy hot displeasure"), Donne reiterates the psalmist's cry for God to "heal me" into a cycle of unmaking and remaking, grounded specifically in an artisanal process. This is a process of reformation in which, like God's "sea of mercie" which "retaines no impression of the ships that passe in it", form is entirely wiped out and made anew. ${ }^{44}$ The responsibility of the subject, of the metal to be (re)worked, is to feel and even delight in being in the middle of this productive crisis: one of "the fearful conditions of God's hot displeasure" (a direct quote from the psalm) would, Donne writes, "to be in a fornace, and not to feel it". ${ }^{45}$ Like Corbett's bell, Donne goes willingly to be reformed, over and over. Donne is the brass and God is the artisan who performs the processes of melting, or sickness, in the materials with which he works.

Health is represented in the Devotions by a different kind of sculptural process, in which the healthy body is compared to stone-Job's other term. When we feel well, Donne writes in the first meditation, "we hew, and wee polish every stone, that goes to that building; and so our Health is a long \& a regular work" (7). We are the artisans here: we shape the individual stones, first by hewing and then by polishing; we care for what we have and we try to make it better, little by little and all the time, refining form gradually by small degrees. In a sermon Donne preached at St Paul's on Christmas Day 1627, echoing the second Meditation of the Devotions, he makes clear the limitations for spiritual growth represented on the one hand by the hardness of stones and on the other by the wateriness of melting snow. 
For me, as I am, I am altogether unfit; when thou shalt be pleased to work upon me, thou wilt finde me but stone, hard to receive thy holy impressions, and then but snow, easie to melt and lose those holy formes again $[\ldots]^{46}$

Stone is hard and not receptive, or at least not able to be worked in any other way than the slow and steady craft of health; snow can only melt, not form again, and it's prone to slip away. This phrase is missing the brass of the second Meditation: matter which is at one moment slippery as water, the next set to the solidity of stone. It's only this matter that is susceptible to the dramatic, generative force of the fever that in an instant "batters all, overthrowes all, demolishes all", and which renders the metal melted and ready to be poured again (7). Sickness is like casting: drastic, sudden, unpredictable, and generative in a very different way to steady, "regular work". It can capture and retain those "holy formes", and in so doing reveal a new form latent in the old.

But there is a further stage in the furnace passage from the second Meditation, in which the fever-stricken body is made first liquid and then a brittle solid: the fever "doth not only melt him, but Calcine him, reduce him to Atomes, and to ashes; not to water, but to lime" (11). In this passage melting goes too far, and turns into calcination. Although this itself represents a kind of dissolution (indeed, it could be the dissolution of stone: marble, when burnt, turns to lime) it seems rather to represent the unproductive destruction associated with sinfulness and hell (a reference to Isaiah 33:12). In a similar passage from a sermon on the Penitential Psalms, Donne compares the holy furnace of the Holy Ghost to the flames of Hell: ${ }^{47}$

If the fires of the holy ghost cannot thaw thee, in his promises, the fire of hell will doe it much lesse, which is a fire of obduration, not of liquefaction, and does not melt a soule, to poure it out into a new and better form, but hardens it, nails it, confirmes it in the old. ${ }^{48}$ 
Here the hardening of hell does not liquefy, but obdures: it is a kind of calcination, very different to the generative casting performed by the Holy Ghost, in which dissolution is a necessary part of the process towards firm form once again.

Calcination, like one of Donne's other favored terms, "transmutation", shows the link here (as elsewhere in his works) to alchemy ${ }^{49}$ But Donne's sculptural metaphors, particularly those to do with melting and casting, provide an analogue to his alchemical ones. The difference between these two sets of metaphors hinges on the question of what has changed once the alchemist, or artisan, has finished his work. ${ }^{50}$ Alchemy promises a change of matter-a transmutation, even transubstantiation, of one substance into another. What Donne is concerned with in these passages in the Devotions is not a change of matter, but rather one of form. Matter is completely dissolved but changed temporarily in its state (that is, solid-molten-solid) and quixotically in its form — but not in the composition of the material of which it is made.$^{51}$ Artisanal processes allow Donne to investigate the significance of changed form but without the troubling, difficult question of transformation of matter. This is why casting in metal—including casting bells in bronze, or brass - is such a powerful metaphor here. By focussing instead on the making and unmaking at the heart of metal-casting, Donne throws the force of interpretation onto the processes of labor and work, and the necessary moments of crisis, that go into creating and recreating forms: a focus that is sustained metaphorically across the content of the Devotions.

\section{SOUND AND THE LABOR OF LISTENING}


We see the poetics of fragmentation and assembly at work even in Donne's description of how bell sounds operate in the Devotions. The sound of bells is usually thought of as centripetal: bringing together the individuals within earshot, calling them into a shared temporal rhythm of work, rest, prayer, and worship. This understanding of them is no doubt important to Donne. The bells in Devotions 16-18 have such a dramatic effect on him in part because he is a careful listener, an interpellated member of the community over which they ring. Although Donne remarked at the great number and weight of the bells in Antwerp and Rouen, neither of these experiences have "affected" him so much as the sound of the bells he hears now, sick in London (82). He understands the message of these local, London bells as being meant intimately for him, "toll[ing] for thee" (87). In Expostulation 16 Donne addresses these concerns directly, proposing for bells an important function that hinges on their efficacy at constituting and maintaining a community. It "is so farre true", he continues, that bells do drive away evil spirits:

as that the evill spirit is vehemently vexed in their ringing, therefore, because that action brings the Congregation together, and unifies God and his people, to the destruction of that Kingdome, which the evill spirit usurps. (83)

Rather than being effective because of those magical functions attached to bells in the preReformation church, the bells' value now lies in the way they create a community from the people within earshot who understand the nuance of their sounds. But bells do not only "[bring] the Congregation together": they also separate it out. Bells are complicit, indeed effective, in processes of division and reformation of both the individual and the social body — and their sounds work in the Devotions in a way that mirrors the dissolution and reassembly of material bodies that we have already explored. 
“[W]ho bends not his eare to any bell, which upon any occasion rings?", asks Donne in Meditation 17, "but who can remove it from that bell, which is passing a peece of himselfe out of this world?" (87). The aural is, here, material: the bell's sound has the power to remove a "peece" of the dying man. And, just as each bell passes a "peece" of the individual's body, or soul, each individual is "a peece of the Continent, a part of the maine" (87): by process of synecdoche, the sound of the bell both fragments into pieces and suggests the ways in which these small parts form components of a social whole. In doing so, these processes emphasize the composition - the matter, even — of the congregation over and above one single instance of its form.

Bells are particularly good at expressing the relay between pieces and wholes in part because of the way in which they can ventriloquize. Over the course of the 16th Expostulation to the 17th Prayer, which includes most of the bell sequence, the bell takes on the voices of a series of speakers: the preacher of the sermon that Donne is unable to hear properly (84); the dead man (85); and finally the voice of God (89). The bell is uniquely able to take on different voices and, in so doing, emphasizes the particularity of these individual voices even as it also shows how they might join together again — not in indistinction, but rather in a kind of harmony among all the different "peeces". This effect is similar to that of the congregation singing a psalm, in which Donne is able to join from his sickbed (84). ${ }^{52}$ These successive acts of ventriloquy are part of the same mechanism that means that each bell "tolls for thee" (87): the bell can both speak as and speak to any of its hearers. 
Robert Reeder makes the important observation that, in these passages, Donne "inverts" Paul in 1 Corinthians: "THOUGH I speak with the tongues of men and of angels, and have not charity, I am become as sounding brass, or a tinkling cymbal" (13:1). Instead of the sad transformation from a human speaker to a trivial, mineral, tinkling thing, in the Devotions the "sounding brass" - the bell—-takes on the voices of men, even of God. We have already seen how longstanding anthropomorphism made bells speaking subjects in a way that complicated any simple description of them as inert or inanimate; we have also seen the ways in which, in a reversal of Job 6:12, flesh becomes brass. Here, the bell takes on the life of the now-dead man: the bell's clapper becomes a human tongue, and allows the human voice to speak, or preach, through its ring. It is for this reason that Reeder suggests that the bells "might operate as a metaphor for the Devotions, which conveys Donne's ordeal—and therefore the message of mortality - to the reader much as the bells convey the ordeal of the neighbor to Donne". ${ }^{53}$ The bells operate as a messenger, or a participant in a conversation: no longer an aid for the purgatorial journey of the dead man, but a way for him to speak again, as Holdfield's bell does, to "the ears of the living".

The bells encourage us to think about the receptive act of listening as something that is active, mutable, and difficult. Bells are both centripetal and centrifugal: they can create a community; they can also separate out that community into just one individual voice, or ear, at a time. A good listener can parse these nuances. And, just like the variously interpretable sounds of the bells, the Devotions call upon a reader who is knowledgeable and flexible: a sensitive interpreter. The form of the text allows for different—even divergent—readings so that the writing here requires an expert and discerning audience. Whereas for Corbett et al., it is the bell-founder (or the bell 
himself) who has the power to re-form, for Donne the skills and labor needed in order to make new forms can be practiced not only by the artisan (or author) but also by the reader him or herself. The form of the Devotions is deliberately open and mutable: it invites fragmentation and reassembly, and in so doing provides not only a way to mirror Donne's own crisis, but shows also how not just the founder but also the writer and even the reader can also be a kind of maker.

\section{FORM, MELTING, AND THE READER'S WORK}

The Devotions was, unusually for Donne, swiftly published. The first edition (1624), printed in duodecimo, conforms to the small size that was customary for personal devotional literature but, coming in at over 600 pages, its physical bulk is considerable. ${ }^{54}$ It leaves generous margins for Donne's own printed marginalia and, potentially, the annotations of readers - but this means that the text is very fragmented, with even the densest pages containing an average of only about 80 words. Despite its heft, the Devotions imagines its own dissolution — not only in its separable formal elements, but also in the moment in the middle of the bell sequence when Donne describes the physical and social body as a book. "All mankinde is of one Author, and is one volume", he writes; at death each person, each "Chapter", is "translated into a better language". "Gods hand is in every translation", he continues, "and his hand shall binde up all our scattered leaves againe, for that Librarie where every booke shall lie open to one another" (86). The passage comes from the $17^{\text {th }}$ Meditation, and it's not a coincidence that the phrase about scattered pages being bound together again comes in the middle of the bell section: a portion of the Devotions which is so concerned at once with the centripetal functions of bells which bring together scattered listeners, and with the ways in which parts and wholes connect. Bodies, 
communities, and metals are all available for reformation — and so are books, even the one the reader now holds in her hands.

The form of the Devotions, with its series of stations, its string of meditations, expostulations, and prayers, is modular, repetitive, and recursive. It does have a tether: the Latin poem right at the beginning gives a précis of the whole text and then, excerpted line-by-line with English translation at the start of each Devotion, runs like a chain from the beginning to the end. But the Devotions as a whole escapes this rein, resisting teleology to provide instead, at a small and large scale, opportunities for relapse, return, and regeneration. Throughout, Donne makes his work visible; the Devotions exposes its workings and its structure, suggesting latent new forms and arrangements not obvious in the codex. Its form implies process: it invites opportunities (sometimes competing ones) for the reader to both take apart and reassemble the text.

It is clear that Donne intended the Devotions to be read in a way that parallels or even participates in the experience that he himself underwent when living the events they describe: an experience which did not follow a straight line, from sickness to health, but rather moved incrementally, looping with stutters and relapses just as frequently as moments of improvement. ${ }^{55}$ Formal difficulty is a way for Donne to model and address bodily spiritual crisis in his readers. ${ }^{56}$ The Devotions differs from other devotional forms, as Kate Narveson points out: Donne offers a model for how a believer must "range through the books of Scripture and Nature for signs and evidences"- a survey that must cover not only these other texts (as Donne did when writing the Devotions, the traces of which we see in his printed marginalia), but also the 
very pages of the Devotions themselves. ${ }^{57}$ The text implies an individual, non-sequential reader who is able to parse a text which is at once formally strict, and open and reformable.

This active readerly work is interpellated as early as the titlepage. Below the title, the page divulges the text's form, explaining that the Devotions as a whole have been:

Digested into

\section{MEDITATIONS upon our Humane Condition}

\section{EXPOSTULATIONS, and Debatements with God.}

3. PRAYERS, upon the seuerall Occasions, to him. (1; italics in original)

Whether this is an authorial intervention or an addition by someone else involved in the making

of the book, it makes the parts distinct and clear, but also —in the word "digested"-suggests the Senecan metaphor that links the labor of reading with the bodily concerns of the work as a whole. ${ }^{58}$ This is a text that was digested in its creation, and should be digested by each individual reader, too. For Nancy Selleck, the tripartite structure of each devotion repeatedly "keeps reenacting a kind of digestive process" which, "repeated over and over, resembles one of digestion — of taking something in, grappling with it till it becomes part of oneself and till one's "disposition" is changed by it." ${ }^{\prime 9}$ But it is not only, as Selleck says, that the text modifies the reader. The opposite is true too: text and reader operate in symbiosis, with the form of the Devotions encouraging an active reading: by being read, reread, and digested, the text changes the reader; and in reading, the reader alters the text from its form as laid out in the codex.

The flexible form of the Devotions has an analogue in the melting trope that runs throughout. The various types of matter-Donne's prose, the physical book, and the metal he describes- 
have to be available for processes of both dissolution and reassembly. But there is a further connection between these two aspects of the text, too: melting is, for Donne and his contemporaries, a way to describe particular kinds of readerly or auditory response. A long tradition of secular verse - deriving from Petrarch and including Donne's own "So let us melt", in "A Valediction Forbidding Mourning"- uses the erotics of melting to describe desire and sexual pleasure. ${ }^{60}$ And in classical rhetoric, Quintilian designated the grand style as one which moves, even manipulates, the listener through extreme effects. ${ }^{61}$ Donne explicitly links this to a kind of sculptural remaking: "Rhetorique", he wrote in a sermon preached at the Hague in 1619 (revised 1630), works "to shake that beliefe, with which it had possessed it self before, and then when it is thus melted, to powre it into new molds, when it is thus mollified, to stamp and imprint new formes, new images, new opinions in it". ${ }^{2}$ Over and over in the sermons, Donne modifies this trope to describe the actions of not only an orator but also a good listener-one with an open ear and open heart—as a kind of melting: the holy spirit, he declared at St Pauls in Easter 1624, "that knowes thy spirit, he that knowes whether thou wert moved by a Sermon, melted by a Sermon, mended by a Sermon, he knows whether thou be alive or no". ${ }^{63}$ Izaak Walton described Donne's own audience as being "melted and moulded [...] into a companionable sadnesse" while listening to him preach. ${ }^{64}$ In all these examples, the receptive modes of reading or listening cause a transformation of the subject, one that can be described by the procedures of first melting and then molding back into shape.

As we have seen, for Donne one of the most valuable characteristics of metal-casting is that it can be done over and over: "Let God mould me, and then melt me againe, let him make mee, and then breake me againe". ${ }^{65}$ The repetition-that "againe"-is important. It appears often, in the 
"scattered leaves" that will be bound up again after the Resurrection (86); also in Corbett's Great Tom, who is "growne yonge againe"; or Osney Abbey, whose "reliques build thee up againe" ${ }^{66}$ The iterative process of melting and making that is contained within the "againe" is what allows for regeneration and progress, as with Great Tom; for Donne, this continues until death brings a more final transformation. Melting is not the final stage in a sequence but a productive, if dramatic, part of a cycle — one which, in terms of literary response, marks the moment at which the reader (or hearer) and the text reach a productive fusion. It's important to be aware of being in the intermediate, melted state - the worst thing of all would be "to be in a fornace, and not to feel it". ${ }^{67}$ Instead one must go willingly to be moved, molded, and re-made — whether this is when you are sick, when going to the sermon with an open ear, or when reading a devotional text ready to learn from it. And in order to make the most of these interstices, to turn them into something useful, we need skill. This is where processes and makers come in: artisans are important models for this kind of work. You need to feel the furnace and, in feeling it, know how to shape the matter into something new.

The melting and metal-casting metaphor promises for form a circularity, a temporary or conditional nature that can be changed according to need or use. Matter is precious and should be cared for, but form's value lies precisely in its contingency and iterability - it is able to inhabit the time of the "again", replete with possibility. The bells in the Devotions, and in the work of such contemporaries as Corbett and his followers, offer models for how renaissance writers made use of the problematic materiality of pre-Reformation objects: matter that was handed down, as well as things that might be re-made. For Corbett et al., form's circularity has an ideological function: matter is reassuringly preserved and so something of the pre-Reformation past remains, 
even though times and forms have changed. While Donne is concerned with the reuse of Reformation objects, he also uses bells in the Devotions as a way to highlight process: a kind of ongoingness that is reflected in the form of the text—his devotions are, after all, "emergent". ${ }^{68}$ By introducing the processes of formation that operate between form and matter, Donne shows how the creative and receptive techniques of putting together and breaking apart are just as "language-soaked" as the objects he considers. In his artisanal poetics, the labor of the work's creation is not only evident in its form but is also replicated in its reception. We are involved in ceaseless work: that of reading and — its analogue — of maintaining bodily and spiritual health. This is why, despite the happy ending of Donne's recovery, the final Devotion is concerned so deeply with his almost inevitable relapse: for a text truly to model this state of alarm for its readers, it must constantly demand our labor.

What might be the consequences of a wider emphasis, in literary study, of the processes of artistic work? What might it look like, to borrow Jonson's gerund again, to focus on how poets themselves put "the doing" at the heart of their writing, as Donne has done here? What might we notice about these texts if we pay attention not only to form and matter, but also to formation? ${ }^{69}$

Such a focus might reanimate the connections between writing and other forms of making that were so important to early modern authors, Jonson included. Current practice-as-research projects in the histories of art and science, including studies of recipes and food cultures, might prove to be useful interlocutors. ${ }^{70}$ These follow textual instructions to replicate, as far as possible, early modern labor; they take seriously knowledge about the behaviors and properties of materials. Literary study might not only learn from but also contribute to such projects' 
emphasis on the relationship between writing and experience. The point is not only, as Donne wrote, "to be in a fornace" but to "feel it"- and to write it. ${ }^{71}$

A focus on processes of formation in literary studies might, further, provide a bridge between the sometimes distant schools of formalism and materialism. Studies of the material text show us how matter and form are always dependent on each other, but I propose a wider emphasis on the making of forms - how we get to formalism, if you like — which attends to writing as a kind of labor. This may even suggest some ways to reconcile the study of material culture with its estranged relative, cultural materialism. And finally, as Donne shows us so well in the Devotions, reading can itself be a kind of work. I suggest that we pay more attention to matter and form, to materials and process, and to the skills needed in order to transform stuff into things. By so doing we can think again about literary form as something that is not just received but made, and made again, in the endless work of our reading.

\section{UNIVERSITY OF YORK}

I'm grateful to The Queen's College, University of Oxford, for the research time and support that allowed me to write this article. Thank you to the Crossroads of Knowledge project at the University of Cambridge, and especially Subha Mukerji, Lizzie Swann, and Becky Tomlin, for inviting me to give an early version of this paper at their 'Matter at the Crossroads' conference in 2016; thank you to the anonymous readers at ELR for their helpful comments. Thank you, finally, to Dianne Mitchell and Nick Gaskill for helping me get this article into its proper shape. 
${ }^{1}$ John Donne, Devotions Upon Emergent Occasions, ed. Anthony Raspa (New York, 1987$), 87$. All further references will be to this edition, given parenthetically in the text.

${ }^{2}$ The dissolving conceit, and the concern with bodies, is widespread throughout Donne's poetry and prose. See for instance, John Carey, John Donne: Life, Mind, and Art, $2^{\text {nd }}$ edn (London, 1990) 160-183; Philip Schwyzer, Archaeologies of English Renaissance Literature (Oxford, 2007), 138150; Ramie Targoff, John Donne, Body and Soul (Chicago, 2008), 130-53.

${ }^{3}$ Some important studies include Douglas Bruster, "The New Materialism in Renaissance Studies" in Material Culture and Cultural Materialisms in the Middle Ages and Renaissance ed. Curtis Perry, Arizona Studies in the Middle Ages and the Renaissance 5 (Turnhout, 2001), 22538; Rayna Kalas, Frame, Glass, Verse: The Technology of Poetic Invention in the English Renaissance (Ithaca, 2007); Patricia Parker, “'Rude Mechanicals"”, in Subject and Object in Renaissance Culture, ed. Margreta de Grazia, Maureen Quilligan, and Peter Stallybrass (Cambridge, 1996), 43-82; Chloe Porter, Making and Unmaking in Early Modern English Drama (Manchester, 2013); Colleen Ruth Rosenfeld, Indecorous Thinking: Figures of Speech in Early Modern Poetics (New York, 2018); Henry Turner, The English Renaissance Stage: Geometry, Poetics and the Practical Spatial Arts (Oxford, 2006) and "Nashe's Red Herring: Epistemologies of the Commodity in Lenten Stuffe (1599)", ELH 68 (2001), 529-561; Jessica Wolfe, Humanism, Machinery, and Renaissance Literature (Cambridge, 2004). Bruster, 232-8, and Turner 2001, 544-51, in particular, productively seek to reconcile "material culture" with the concerns of Marxist cultural materialism. See also Jonathan Gil Harris on the importance of thinking about matter through time, Untimely Matter in the Time of Shakespeare (Philadelphia, 2009), 7-8. 
${ }^{4}$ George Puttenham, The Art of English Poesy, ed. Frank Whigham and Wayne A. Rebhorn (Ithaca, 2007), 93. See also Philip Sidney’s discussion of this etymology, “The Defense of Poesy" and Selected Renaissance Literary Criticism, ed. Gavin Alexander (London, 2004), 8. ${ }^{5}$ Ben Jonson, Discoveries, ed. Lorna Hutson, in The Cambridge Edition of the Works of Ben Jonson (Cambridge, 2012), VII: 579; it is Jonson's adaption of a section from Jacobus Pontanus, Poetatum institutionem libri tres (Ingolstadt, 1594). Colleen Rosenfeld discusses Jonson's passage in Indecorous Thinking, 2-3.

${ }^{6}$ Robert Whiting, The Reformation of the English Parish Church (Cambridge, 2010) 178, gives the founder's name as Oldfield; see also Walters, Church Bells of England (London, 1912) 335 and, on Holdfield, 239. In Broken Idols of the Reformation (Cambridge, 2015), Aston, following Walters, dates this bell to the early seventeenth century, certainly 1599-1612 (472).

7 Walters 261, 268.

${ }^{8}$ They were not mentioned in Edward's Injunctions of July 1547 which ordered parishes to "take away, utterly extinct, and destroy" many religious objects but their use, and number, was restricted: the Injunctions expressly allowed only "one bell in convenient time to be rung or knelled before the sermon" (Tudor Royal Proclamations Vol. I: The Early Tudors (1485-1553) ed. Paul L. Hughes and James F. Larkin (New Haven, 1964), 401, 399). Elizabeth protected the material of bells, issuing a proclamation in 1560 that "doth expressly forbid any manner of person to take away any bells or lead of any church or chapel now used"; and in a Royal Order of the same year, "that there be no destruction or alienation of the bells, steeple, or porch belonging to any parish church" (Tudor Royal Proclamations Vol. II: The Later Tudors (1553-1587) ed. Paul L. Hughes and James F. Larkin (New Haven, 1969), 148; Walter Howard Frere, ed., Visitation Articles and Injunctions of the Period of the Reformation, (London, 1910), III: 109). 
${ }^{9}$ Aston, 447; see 446-488 for a full discussion of bells in the post-Reformation church. Richard Strier argues that the bell sequence in the Devotions signals Donne's commitment to “Arminianism and polemical anti-puritanism". I think instead that Donne positions himself between two extremes: Catholics (who think that bells have an active role in the liturgy, and have powers that include driving away spirits); and strict nonconformists (who think we should do away with them altogether). But the space in between these two was considerable, and contained multitudes - this is partly why bells had been able to survive. Donne's attitude towards them here signals only that he has a place somewhere within the vast middle ground on the subject. Strier, 'Donne and the politics of devotion', Religion, Literature, and Politics in PostRef England ed. Donna B. Hamilton and Richard Strier (Cambridge, 1996) 93-114, at 106. ${ }^{10}$ Whiting (175-76) notes that there exist no extant, dated bells from when the latter was king. Walters $(215,221)$ suggests that there was regional variation: some areas, like London, saw very little bell-casting done from after the dissolution until the 1570s; in other places, like Berkshire, a small number of foundries continued to work throughout the sixteenth century. Much of what we know is due to the extensive, county-by-county bell catalogues that were assembled from the mid-nineteenth century onwards, which were based on both material evidence of existing bells, and on combing through parish records - but these records don't necessarily include bells that were destroyed in the centuries-long interim.

${ }^{11}$ Walters, 215-55. The increased production of bells was motivated by a combination of factors, including a renewed attention to the fabric of the church; and the invention of change-ringing. The latter, a new method of ringing which began in the early seventeenth century, required ever more bells to ring its complicated series of permutation. On change-ringing, see Katherine Hunt, "The art of changes: bell-ringing, anagrams, and the culture of combination in seventeenth- 
century England", The Journal of Medieval and Early Modern Studies 48 (2018), 387-412, and

Christopher Marsh, Music and Society in Early Modern England (Cambridge, 2010), chap. 9.

${ }^{12}$ On this indeterminacy see David Ekserdjian, "Bronze: An Introduction”, in Bronze, ed. David Ekserdjian (London, 2012), 12; and Peta Motture, Bells and Mortars (London, 2001), 18-23.

${ }^{13}$ For a detailed description of the process see Walters, 36-47.

${ }^{14}$ See, for example, the large bell of St Michael, Cornhill known as Rus. This medieval bell developed flaws so that, in 1587 , the parish had it melted down and re-made. Unfortunately, its new sound was no good either, so it was re-cast again the following year. Throughout these several re-castings the bell continued to exist, with the same name throughout: Rus. See W. Overall (ed.), The Accounts of the Churchwardens of the Parish of St Michael Cornhill (London, 1869), 176-79.

${ }^{15}$ On the vitality of bronze see Martina Droth, ed., Bronze: The Power of Life and Death (Leeds, 2005); Ekserdjian, Bronze; and Ittai Weinryb, The Bronze Object in the Middle Ages

(Cambridge, 2016).

${ }^{16}$ Jane Bennett, Vibrant Matter: A Political Ecology of Things (Durham, 2010), 53.

${ }^{17}$ The date of this recasting is uncertain, in part because it seems to have been recast several times in the first decades of the seventeenth century, records for which are incomplete. Corbett's editors propose a date of 1626, because in this year Corbett himself (as Dean) signed off on a payment to "Keene bellefounder". See The Poems of Richard Corbett, ed. J. A. W. Bennett and H. R. Trevor-Roper (Oxford, 1955), 150. For a discussion of these and other Oxford poems on bell-casting see William Poole, "The Bells of New College, from Five to Eight to Ten”, New College Notes, 2012, https://www.new.ox.ac.uk/node/744, accessed 4 October 2018. 
${ }^{18}$ I am not proposing direct links between Corbett's work and the Devotions, but the two authors did have some connections. Corbett wrote an elegy for Donne, "An Epitaph on Doctor Donne", included in his posthumous collection Certain Elegant Poems (London, 1647, sig. C5r-v.); John Donne Jr had studied at Oxford during Corbett's time there and edited this collection for publication. See Corbett, xlii-xliii. On Corbett's poetry see Christopher Burlinson, "Richard Corbett and William Strode: chaplaincy and verse in early seventeenth-century Oxford", in Chaplains in Early Modern England: Patronage, Literature, and Religion ed. Hugh Adlington, Tom Lockwood, and Gillian Wright (Manchester, 2013), 141-58; Andrew McRae, "Satire and Sycophancy: Richard Corbett and Early Stuart Royalism", The Review of English Studies, new series 54 (2003), 336-64.

${ }^{19}$ Frederick Sharpe, The Church Bells of Oxfordshire, Oxfordshire Record Society vols. 28, 30, 32, 34 (Oxford, 1949-53), III: 233, 236; on the history of the Christ Church bells, III: 227-284, and on the Great Tom bell in particular III: 258-77.

${ }^{20}$ Corbett, Poems, ed. Bennett and Trevor-Roper, 79. All references are to this edition unless specified otherwise.

${ }^{21}$ Corbett, 82.

${ }^{22}$ Corbett, 81.

${ }^{23}$ Corbett, 80 .

${ }^{24}$ Corbett, 81.

${ }^{25}$ Corbett, 98 .

${ }^{26}$ For a (non-exhaustive) list see the Catalogue of English Literary Manuscripts, http://www.celm-ms.org.uk/authors/corbettrichard.html (accessed 4 October 2018). 
${ }^{27}$ Folger MS V.a.97, 36. This poem seems to have been written by an unknown author (sometimes identified as Gervase Warmestry), at the same time as Corbett's poem (Corbett, 149151). A date is given in Folger V.a.97: "On Tom of C: Ch; cast in octob: 1626" (36).

${ }^{28}$ Folger MS V.a.97, 36.

${ }^{29}$ This phrase-- meaning in good condition, undamaged — was certainly in use by this time; in Much Ado About Nothing, Don Pedro describes Benedick's heart as "as sound as a bell" (3.2.11; TLN 1210).

${ }^{30}$ On metal, mettle and the analogy between flesh and earth see Gail Kern Paster, Humoring the Body: Emotions and the Shakespearean Stage (Chicago, 2004), 36-47.

${ }^{31}$ London was probably suffering an epidemic of typhus; see Mary Ann Lund, “Donne's convalescence”, Renaissance Studies 31 (2016), 532.

32 These bells ring at the time of death of a parishioner-but not, as in the pre-Reformation church, to help the passage of the dead person's soul through purgatory. Instead, they were meant only to inform, prompting (non-intercessory) prayers for the dead, and to remind their hearers that their time would soon be up. Holdfield's bell sounds "to the ears of the living", demanding to be received correctly, by living listeners - it is not ringing "for the souls of the dead". The need to deny this latter function was important, in order to distinguish present practice from Catholic precursors, although perhaps the very need to deny bells' former functions suggests that old meanings continued to lurk. For all his affirmation of indifference towards these objects, Donne recalls in the Devotions instances of bells ringing on their own, for example: doing things that surely recall the "abuses" of them that he elsewhere disavows (82, 83). As Robert Reeder points out, the bells operating as a kind of prayer for the dead is one way in which they seem to hang on to some of their pre-Reformation associations ("“"Charitable 
Extasie' and Prayer for the Dead in Donne's Devotions upon Emergent Occasions", SEL 56 (2016), 93-110, at 100-06). On the reformation of ringing practices, and the tenaciousness of older forms of ringing, see Vanessa Harding, The Dead and the Living in Paris and London, 1500-1670 (Cambridge, 2002); Peter Marshall, Beliefs and the Dead in Reformation England (Oxford, 2002) especially 128-32; Matthew Milner, The Senses and the English Reformation (Farnham, 2011), 298-99.

${ }^{33}$ Elaine Scarry, "Donne: But Yet the Body is his Book", in Literature and the Body: Essays on Populations and Persons, ed. Scarry (Baltimore, 1988), 92. See also Targoff, John Donne, 2548.

${ }^{34}$ Aston, 453, and 453 n28.

${ }^{35}$ Raspa, 171 (note to p.82 line 7-8).

${ }^{36}$ All Biblical references are to the Authorized Version (1611).

${ }^{37}$ Janel Mueller discusses the often antagonistic, questioning nature of the Biblical quotations in the Devotions, and particularly the Expostulations, in "The Exegesis of Experience: Dean Donne's "Devotions upon Emergent Occasions", The Journal of English and Germanic Philology 67 (1968), 1- 19, at 3.

${ }^{38}$ Nancy Gail Selleck, “Donne’s Body”, Studies in English Literature 1500-1900, 41 (2001), 149-74, at 168; Schwyzer, 143.

${ }^{39}$ Carey, 160 .

${ }^{40}$ Carey, 172 .

${ }^{41}$ Targoff, 138.

${ }^{42}$ Targoff, 153. 
${ }^{43}$ The Sermons of John Donne, ed. George Potter and Evelyn Simpson, 10 vols. (Berkeley, 195362), V: 335 . Hereafter "Sermons", and cited by volume and page number. These undated sermons on the penitential psalms have long been proposed as precursors to the Devotions (Mueller, 8-9, 19).

${ }^{44}$ Sermons, V: 318.

${ }^{45}$ Sermons, V: 335.

${ }^{46}$ Sermons, VIII: 131.

${ }^{47}$ We don't know when this sermon was preached, but probably not in 1623; Potter and Simpson suggest it dates to the winter of 1624-5. Sermons, IX: 37.

${ }^{48}$ Sermons, IX: 291

${ }^{49}$ For Katherine Eggert, Donne uses alchemy as a trope that is both trivial, and metaphorically appealing — an example of "disknowledge". She gives a thorough reading of Donne's interest in alchemy, and its critical literature, in Disknowledge (Philadelphia, 2015), 55-109, esp. 70-92. ${ }^{50}$ Of course there was much overlap between the work of the alchemist and that of the artisan. On the relationship between the two see Pamela H Smith, The Body of the Artisan (Chicago, 2004), and William Newman, Promethean Ambitions: Alchemy and the Quest to Perfect Nature (Chicago, 2004).

${ }^{51}$ Brass is a better model than gold here because of its ability to be melted and reformed. Elsewhere in Donne's writing gold is sometimes imagined to be melted (like the gold coins in "The Bracelet") but more often it's hammered out, "to aery thinness beat" its ductility being the more important quality (“A Valediction Forbidding Mourning", line 24; in The Complete Poems of John Donne, ed. Robin Robbins, rev. ed. (Abingdon, 2013), 259). On gold see Carey, 162-63, $170-72$. 
${ }^{52}$ Donne's emphasis on pieces is important. I agree with Jessica Tabak here, who writes that "To be a "piece" or a "part" suggests that Donne belongs to a primary body while maintaining distinction from it” (“'O Multiplied Misery!': The Disordered Medical Narrative of Donne’s Devotions", The Journal of Medieval and Early Modern Studies 46 (2016), 183). Tabak distinguishes herself from Kate Frost who proposes that Donne and his readers "eschew particularity as we dissolve into a single Christian body, with a single Christian voice." (Frost 38). On harmony in communal singing see Ramie Targoff, Common Prayer (Chicago, 2001), chap. 3 and Marsh, chap. 8.

${ }^{53}$ Reeder, 93-110, at 99.

${ }^{54}$ The Bodleian Library's copy of the first edition (shelfmark Don. f.190) measures (in mm) 84 W x $142 \mathrm{H}$ x $37 \mathrm{D}$. The pagination runs to 630 with signatures to Ee3v. The fourth edition (1634) was in $24 \mathrm{mo}$, but omitted both the margins and the marginalia, making for a denser text. A high-quality scan of the 1624 edition is available at http://drc.usask.ca/projects/ark/published/Donne/DevotionsStAndrewsReduced.pdf ${ }^{55}$ Tabak, 168, 180 and Targoff, John Donne, 137. ${ }^{56}$ For Jessica Tabak, formal difficulty and the disordered narrative of the Devotions shows Donne's reworking of the Augustinian notion of distentio animi, in which the mind distends across past, present, and future.

${ }^{57}$ Kate Narveson, "The Devotion", in The Oxford Handbook of John Donne, ed. Dennis Flynn, M. Thomas Hester, and Jeanne Shami (Oxford, 2011), 316. Katharine Craik argues that Donne reads his own symptoms: "Donne compares his illness to a literary fragment, and its symptoms to the instruments of writing and print." Reading Sensations in Early Modern England (Basingstoke: 2007), 90. Stanley Fish describes another variety of readerly work that Donne 
demanded of the readers, or hearers, of his sermons, and in some ways the Devotions model what Fish argues about Deaths Duell: that the texts is 'a presentation that unsettles the mind and demands, literally, that it change'. Unlike the sermon the Devotions do not only demand but, in their form, actually model the change that the reader is asked to make. Self-Consuming Artefacts, $2^{\text {nd }}$ edn (Pittsburgh, 1994), 43-77, at 77.

${ }^{58}$ Selleck (164) ascribes this passage to Donne because of his interest in digestion as a metaphor in this period. Processes of digestion are important for Donne's convalescence, too: at the start of the $20^{\text {th }}$ Devotion, Donne suggests that signs of digestion in his urine operate as a sign to his doctors that he's beginning to recover (104).

${ }^{59}$ Selleck, 165.

${ }^{60}$ Donne, Poems, 258 (line 5). On the erotics of melting in early modern poetry see Andrea Brady, "The Physics of Melting in Early Modern Love Poetry", Cerce: An Australasian Journal of Medieval and Early Modern Studies, 1 (2014), 22-52.

${ }^{61}$ See, for example, Quintilian, The Orator's Education, ed. D. A. Russell (Cambridge, MA, 2014), V: 314-5 (Institutiones 12.10.61-2).

${ }^{62}$ Sermons, II: 282. In this passage Donne compares the complexity of the rhetorician's work to the simplicity of Christ's calling to Peter and Andrew: "Follow me" (Matthew 4:19).

${ }^{63}$ Sermons, VI: 71. This sermon which, appropriately given the occasion, was profoundly concerned with resurrection, was likely to have been the first one Donne gave following his recovery. See Mueller, “The Exegesis of Experience”, 16.

${ }^{64}$ Izaak Walton, The Life of John Donne (London, 1658), sig. D2r.

${ }^{65}$ Sermons, V: 335.

${ }^{66}$ Corbett, 79,81 
67 Sermons, V: 335.

${ }^{68}$ I borrow the word "ongoingness" from Sarah Manguso, Ongoingness: The End of a Diary (Minneapolis, 2015), in which Manguso examines her own practice of keeping a journal.

${ }^{69}$ Jonson, VII: 579. Many of the critics I've cited above are, as are many others, engaged in strands of the kind of work I propose here; my purpose in this conclusion is not so much to provide a bibliography of such work, but rather to draw together an outline of some of its benefits.

${ }^{70}$ See, for example, the Making and Knowing Project, based at Columbia University; www.makingandknowing.org; ARTECHNE: Technique in the Arts, 1500-1950, at the University of Utrecht https://artechne.wp.hum.uu.nl/; The Recipes Project, https://recipes.hypotheses.org/; Cooking in the Archive https://rarecooking.com/. Literary scholars already contribute to these projects and their questions of textual transmission (the founders of Cooking in the Archive, for example, are two scholars of early modern literature).

${ }^{71}$ Sermons, V: 335. 